\title{
Corneal Graft Success Rates in HSV Keratitis: A Systematic Review
}

\author{
Konstantinos Skarentzos, Eleftherios Chatzimichael, Eirini-Kanella Panagiotopoulou*, \\ Sergios Taliantzis, Aristeidis Konstantinidis, Georgios Labiris
}

\begin{abstract}
Herpes Simplex Virus (HSV) has worldwide prevalence. The primary objective of this systematic review was to compare penetrating keratoplasty (PK) and deep anterior lamellar keratoplasty (DALK) regarding the efficacy and complications of the treatment of corneal scarring caused by herpes simplex keratitis. Out of the 469 articles identified during the combined search of the literature based on the PubMed and Cochrane libraries, 10 retrospective and 2 prospective studies published from January 2010 to December 2019 were included. The study outcomes indicated that both surgical approaches resulted in a comparable improvement of visual acuity (VA). However, DALK demonstrated fewer complications in the majority of studies. Higher graft survival rates were associated with higher acyclovir (ACV) doses (above $800 \mathrm{mg} /$ day), topical steroid and antibiotic drops. In conclusion, in terms of postoperative VA, both PK and DALK demonstrate comparable efficacy. However, DALK, which is applied in less severe HSK cases, is associated with fewer complications and better graft survival rates. High dosages of ACV, topical steroids and antibiotics contribute significantly to improved postoperative outcomes.
\end{abstract}

\section{KEYWORDS}

herpes simplex virus; herpes simplex keratitis; penetrating keratoplasty; deep anterior lamellar keratoplasty; systematic review

\section{AUTHOR AFFILIATIONS}

Department of Ophthalmology, University Hospital of Alexandroupolis, Dragana, Alexandroupolis, Greece

* Ophthalmology Department, University Hospital of Alexandroupolis, 68100 Dragana, Alexandroupolis, Greece;

e-mail: eipanagi@med.duth.gr

Received: 15 July 2020

Accepted: 2 October 2020

Published online: 22 December 2020

Acta Medica (Hradec Králové) 2020; 63(4): 150-158

https://doi.org/10.14712/18059694.2020.57

(c) 2020 The Authors. This is an open-access article distributed under the terms of the Creative Commons Attribution License (http://creativecommons.org/licenses/by/4.0), which permits unrestricted use, distribution, and reproduction in any medium, provided the original author and source are credited. 


\section{INTRODUCTION}

Herpes Simplex Virus (HSV) which belongs to the herpesvirus family is usually asymptomatic, however, it may affect a great variety of organs (1-2). It is estimated that in the U.S. alone 500,000 people suffer from ocular HSV and every year about 50,000 new cases of ocular HSV are diagnosed (3). Following the entry into the host, HSV replicates within the end organ. Following replication, the virus gains the ability to travel up the axon of the corresponding nerve and colonize the corresponding ganglion, where it lies in a latent state (4). For infections involving the face, the trigeminal nerve, which supplies the sensory innervation of the face, and the trigeminal ganglion are involved. In some patients, a number of stimuli, either physical, such as corneal trauma (eye injury, surgery, excimer laser) or other factors such as psychological stress, fever, systemic infection, immunodeficiency, sunlight exposure and menstruation (4-6), trigger reactivation of HSV. As a result, the virus replicates and travels down the axon of the sensory nerve to its target tissue, causing recurrent infection and stimulating an inflammatory response. The spectrum of ocular disease caused by HSV is wide and depends on the target tissue that is infected. Both the anterior and posterior segments of the eye can be involved; among them, herpetic blepharitis, conjunctivitis, keratitis, as well as herpetic uveitis (iridocyclitis or trabeculitis) are some possible manifestations. In the most severe and rare cases, necrotizing herpetic retinopathy may occur with devastating outcomes to the visual capacity.

Regarding corneal disease, Herpes Simplex Keratitis (HSK) is the leading cause of corneal infectious blindness in developed countries (7). HSV has the ability to infect all the layers of the cornea and lead to infectious epithelial keratitis, neurotrophic keratopathy, necrotizing stromal keratitis, immune stromal keratits and/or endothelitis. The most typical lesion of HSK is the dendritic ulcer and the geographic ulcer in severe cases; both can be stained positively with fluorescein. Other examinations such as polymerase chain reaction (PCR), tear collection and immunofluorescence antibody assay (IFA) have also been used in order to identify the virus (4). Corneal epithelium involvement may occur in up to two thirds of the cases with herpetic ocular disease (8). However, the relapsing and recurring disease of stroma and endothelium is responsible for most of the cases of corneal scarring and neovascularization. Disciform keratitis is related to about $2 \%$ of initial ocular HSV presentation. Nevertheless, it is responsible for $20-48 \%$ of disease recurrences (8-9). Herpetic keratitis can result in reduction of visual acuity (VA) to $<6 / 12$ in $10-25 \%$ and corneal scarring in $18-28 \%(9)$. $\mathrm{Pa}-$ tients suffering from HSK usually have a red painful eye accompanied by other symptoms such as discharge, irritation, itching, watery eyes and photophobia.

Acyclovir (ACV), either in topical, oral or intravenous form, remains until today the mainstay of treatment against all herpes ocular disease's types. ACV can be used in combination with corticosteroids or other antiviral drugs like ganciclovir (GCV) or valaciclovir (VCV). However, oral or topical drugs do not eradicate the virus but only lower the risk of recurrence of ocular disease. In case of HSV-induced corneal opacities, surgical debridement may be indicated (4).

Deep anterior lamellar keratoplasty (DALK) is a surgical procedure in which the pathological stroma is excised down to Descemet membrane (DM), leaving the original corneal endothelium intact. As a result, DALK can be used for the treatment of corneal scarring when the endothelium and DM have not been affected (10-12). On the other hand, penetrating keratoplasty (PK) is another surgical technique that could be used in HSK-induced corneal scarring, especially in those cases that is complicated with endothelial insufficiency. However, both DALK and PK suffer from a series of adverse effects (13-15); among them, endothelial rejection, cell loss or failure, damage to the iris and/or crystalline lens, microbial endophthalmitis and expulsive choroidal hemorrhage are part of the spectrum of the complications of PK. On the other hand, ruptures or microperforation of DM, double anterior chamber and recurrence of stromal cornea dystrophy in the residual bed are unique complications of DALK. Moreover, epithelial and stromal immune graft rejection, and graft failure can occur with either procedure and are commonly easily managed with topical corticosteroid drops. Corticosteroid-associated high intraocular pressure (IOP), cataract, decreased wound healing, and compromised local immunity are some additional adverse effects of both procedures, however, with DALK having fewer and less severe adverse effects in comparison with PK (16). Thus, apart from PK and DALK, several approaches have been used for the management of HSV keratitis including therapeutic contact lenses, collagenase inhibitors, tarsorrhaphy, conjuctival flap, and cyanoacrylate gluing (17-18).

Within this context, the primary objective of this systematic review was to compare PK and DALK regarding the efficacy and complications of the treatment of corneal scarring caused by HSK.

\section{MATERIAL AND METHODS}

\section{STUDY DESIGN AND INCLUSION CRITERIA}

This systematic review followed the Preferred Reporting Items for Systematic Reviews (PRISMA) statements checklist (19). The inclusion and exclusion criteria were defined before the initiation of the research. Only original articles and case series with 5 or more subjects were included whose main or secondary goal was to demonstrate outcomes regarding DALK or PK or both interventions in populations suffering from corneal scarring as a result of HSK. Commentaries, conference abstracts, editorials, letters to the editor, case series with less than 5 patients were not considered.

The selection criteria were defined by applying the PICO (Problem/Population, Intervention, Comparison, and Outcome) framework. Participants included immunocompetent adult patients (above 18 years old) with corneal scarring as a result of HSK. Intervention consisted of PK or DALK or both and the following postoperative drug administration. Some of the included studies compared $\mathrm{PK}$ and DALK, but articles in which intervention were PK or DALK without any comparison were also considered. 
Tab. 1 Quality assessment.

\begin{tabular}{|l|l|l|l|l|l|l|l|l|}
\hline Reference & $\begin{array}{l}\text { Year of } \\
\text { publication }\end{array}$ & $\begin{array}{l}\text { Selection } \\
\text { Bias }\end{array}$ & $\begin{array}{l}\text { Study } \\
\text { Design }\end{array}$ & Confounders & Blinding & $\begin{array}{l}\text { Data } \\
\text { Collection } \\
\text { Methods }\end{array}$ & $\begin{array}{l}\text { Withdrawals } \\
\text { and Drop Outs }\end{array}$ & $\begin{array}{l}\text { Global } \\
\text { Rating }\end{array}$ \\
\hline Altay et al.(30) & 2017 & Moderate & Moderate & Strong & Weak & Strong & NA & Moderate \\
\hline Li j. et al.(32) & 2011 & Moderate & Moderate & Strong & Weak & Strong & Moderate & Moderate \\
\hline Li J. et al. (31) & 2014 & Moderate & Moderate & Strong & Weak & Strong & NA & Moderate \\
\hline Li S. et al.(22) & 2019 & Moderate & Moderate & Strong & Weak & Strong & Strong & Moderate \\
\hline Liu et al.(26) & 2016 & Moderate & Weak & Strong & Weak & Strong & NA & Weak \\
\hline Lyall et al.(27) & 2012 & Moderate & Weak & Weak & Weak & Strong & NA & Weak \\
\hline Ren et al.(28) & 2016 & Moderate & Weak & Strong & Weak & Strong & NA & Weak \\
\hline Sarnicola et al.(21) & 2010 & Moderate & Weak & Strong & Weak & Strong & NA & Weak \\
\hline Shimizu et al. (23) & 2017 & Moderate & Weak & Strong & Weak & Strong & NA & Weak \\
\hline Wang et al.(29) & 2012 & Moderate & Weak & Strong & Weak & Strong & NA & Moderate \\
\hline Wu et al.(24) & 2012 & Moderate & Moderate & Strong & Weak & Strong & NA & Weak \\
\hline Zheng et al. (25) & 2009 & Moderate & Weak & Strong & Weak & Strong & NA & \\
\hline
\end{tabular}

NA: Not applicable

DALK was primarily indicated when the endothelial layer and the DM of the cornea remained healthy with no sign of stromal edema, while PK was indicated when all corneal layers (epithelium, stroma and endothelium) were affected or, in specific, when corneal endothelial cell count was $<700$ cells $/ \mathrm{mm}^{2}$ or was undetectable. Primary outcomes included rate of rejections and VA. Secondary outcomes included rate of recurrence, graft failure, microperforation, double minor anterior chamber, graft melting and any other complications that were reported.

\section{LITERATURE SEARCH STRATEGY}

A literature search was performed based on the PubMed and Cochrane libraries using the following search terms: (HSK OR herpes simplex keratitis OR herpes OR herpes simplex virus OR HSV) AND (corneal scar OR PK OR penetrating keratoplasty OR DALK OR deep anterior lamellar keratoplasty). Moreover, the reference lists of the eligible studies and relevant review articles were cross-checked to identify additional pertinent studies. We retrieved articles published in English, French and German from January 2010 to February 2020 that met the selection criteria.

\section{STUDY SELECTION AND QUALITY ASSESSMENT}

The records found were checked for duplicates. Then, two independent reviewers who were blinded to each other decisions screened the articles first by title and abstract and after that full-text screening was conducted. Any conflict was dissolved by a third reviewer. Risk of bias of the eligible articles was conducted with "Quality Assessment Tool for Quantitative Studies" by Effective Public Health Practices (20). Again, the same two individual reviewers assessed the articles, blinded to each other's decisions and any conflict was resolved by a third reviewer. The results are demonstrated in Table 1.

\section{DATA EXTRACTION}

Data extraction was also carried out by (K.S.) and (E.C.), blinded to each other's decisions and (G.L.) resolved any conflict. The following information were noted: author, year of publication, study location, study design, total patients enrolled in the study, total patients who completed the study, patient demographic characteristics, treatment groups, dose and schedule of interventions, duration of follow-up, primary outcomes (rejection rate for the first rejection episode, VA) and complications.

\section{RESULTS}

\section{LITERATURE SEARCH AND SELECTION}

Overall, the combined search identified 469 articles. After the removal of duplicates, 435 studies remained. Our criteria were matched in 29 records and they were assessed in full-text form for eligibility. No additional study was identified through cross-check of reference lists. Out of twenty-nine articles, 17 were excluded due to the following reasons; 6 because of underage or immunodeficient subjects, 3 studies because they were not an acceptable article type, 3 because of missing results, 1 due to overlapping population and 4 records because they did not apply the eligible interventions (DALK or PK). A PRISMA flow chart is demonstrated in Figure 1. Finally, the 12 remaining articles were assessed for quality as it was described before and a summary of the results is demonstrated in Table 1.

\section{STUDY CHARACTERISTICS}

The 12 selected studies were published from January 2010 (21) to December 2019 (22). The present review included 10 retrospective $(21,23-31)$ and 2 prospective studies (22, 32 ). The record's subjects varied from 13 eyes of 13 patients 


\section{PRISMA 2009 Flow Diagram}

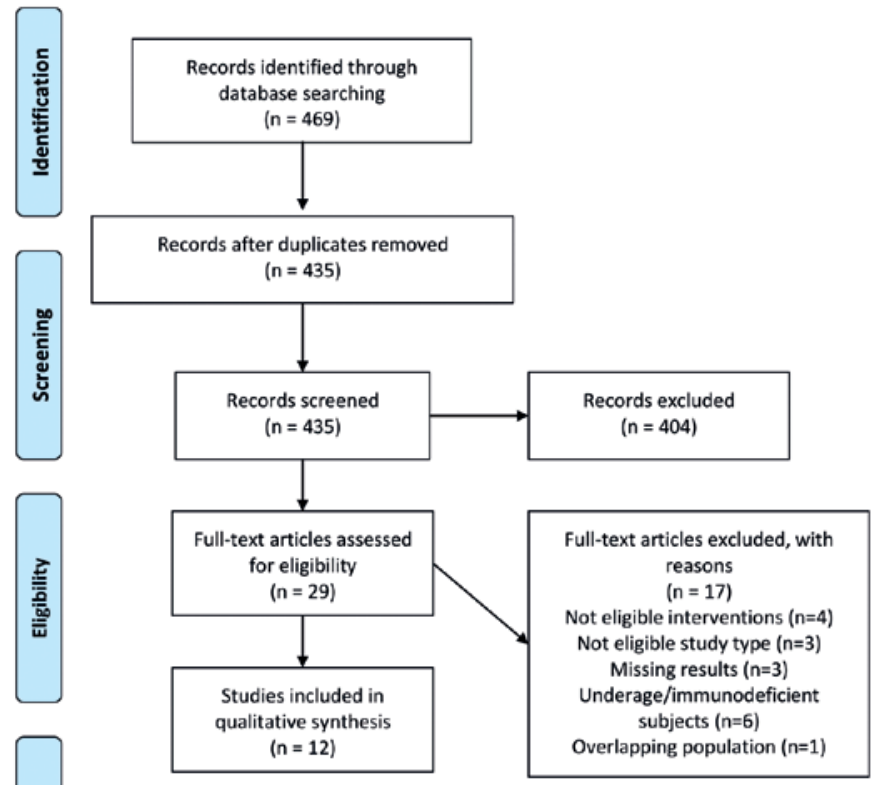

Fig. 1 PRISMA 2009 flow diagram.

Source: Moher D, Liberati A, Tetzlaff], Altman DG, The PRISMA Group (2009). Preferred Reporting Items for Systematic Reviews and Meta-Analyses: The PRISMA Statement. PLoS Med 6(7): e1000097. doi: 10.1371/journal.pmed1000097.

(25) to 121 eyes of 121 patients (24). DALK, using Anwar's big bubble technique (33), was described as the only intervention in 4 records $(21,27-29)$ (Table 2). Other research teams performed: DALK using acellular corneal tissue (ACT) (32), DALK using precut anterior lamellar cap (ALC) (31), acellular porcine corneal stroma (APCS) DALK (22), or DALK using glycerol-cryopreserved corneal tissues (GCCTs) (26) (Table 3). PK as the only intervention was carried out by Altay et al. (30). Shimizu et al. (23), in their comparative study, divided the participants in two groups, one in which PK was performed and another one in which DALK was applied. Wu et al. (24) described case series comparing full-bed deep lamellar keratoplasty (fullbed DLK) and PK (Table 4). In the case series of Zheng et al. (25), PK and DALK were performed but with no comparison between interventions. The extracted data of these 12 articles are shown in Tables 2-4. The postoperative prescriptions are described in "dose and schedule of intervention" section of these tables.

\section{PRIMARY OUTCOMES}

Regarding DALK procedure (Table 2), a significant improvement in vision after the operations was described $(21,27-29)$. The rejection was lower than $5 \%$ in the studies of Ren et al. (28) and Wang et al. (29) in a 50.4-month and 31-month follow-up period, respectively, while no rejection was detected in a 31-month follow-up period according to
Sarnicola et al. (21) records. However, in the study of Lyall et al. (27), the rate of rejection was 50\% during a follow-up period of 56-months. Rejection rate lower than $12 \%$ was noted in DALK using ACT (32) and glycerol-cryopreserved corneal tissues (GCCTs) (26). On the other hand, the rejection was $0 \%$ in DALK using precut ALC (31) and APCS (22) (Table 3). Regarding the postoperative VA, a significant improvement was observed postoperatively after DALK using precut ALC (31) and DALK using GCCTs (26). The VA outcomes in DALK using ACT (32) and in APCS DALK (22) presented in Table 3 were mixed with other types of keratitis. In a case series of Zheng et al. (25), with mixed results of DALK and PK using APCS, VA was improved in $69.2 \%$ of the population and no rejection occurred. In the study of Shimizu et al. (23), PK and DALK procedures achieved similar improvement in VA but no data about the complications were given. PK showed graft rejection lower than $10 \%$ in the study performed by Altay et al. (30) and $93 \%$ of the patients achieved BCVA better than 1.2 logMAR. Last but not least, in the comparative study of Wu et al. (24), PK showed a significantly higher number of graft rejections when compared with full-bed DLK $(41.3 \%$ and $0 \%$, respectively, $\mathrm{p}<0.05$ ). Moreover, the VA was improved in $66.1 \%$ of the eyes that received full-bed DLK and $50.9 \%$ in the PK group.

\section{SECONDARY OUTCOMES}

In DALK procedure, HSK recurrence was observed from $0 \%(21)$ to $33.3 \%$ (27) of the study population. Microperforation in DALK occurred in $3.8 \%$ (21) to $16.9 \%$ (28) of the subjects. In the study of Lyall et al. (27), increased IOP, bacterial keratitis and graft failure was found in $27.7 \%$ of the patients. Several complications including double anterior chamber, corneal endothelial decompensation and posterior stromal folds were described in $10.1 \%, 3.4 \%$ and $46.1 \%$ of the population, respectively, in Ren et al. (28) records. No recurrence was noted in patients who had DALK procedure using ACT (32). In DALK using precut ALC, microperforation was $7.4 \%$ in the FTS group and $4.7 \%$ in the ALC group, double anterior chamber was $14.8 \%$ in the FTS group and $4.7 \%$ in the ALC group, DM folds were $7.4 \%$ in the FTS group and $14.3 \%$ in the ALC group and recurrence was observed in $11.1 \%$ of the population in the FTS group and $14.3 \%$ in the ALC group (31). In APCS DALK procedure, graft failure was described in $57.1 \%$ of the patients, recurrence in $14.2 \%$ and graft melting in $42.6 \%$ (22). In DALK using GCCTs, different complications were observed; among them, microperforation (14.8\%), double anterior chamber (7.4\%) and recurrence (7.4\%) (26). Regarding PK procedure, in the study of Altay et al. (30), among 55 patients, recurrence of HSK was noted in $28.5 \%$. In group 1 , which included patients with quiescent herpetic corneal scar, graft failure was observed in $19 \%$, and graft rejection in $9.52 \%$, while in group 2 , which included patients with a corneal descemetocele or perforation, graft failure was noted in $30.8 \%$ and graft rejection in $23.07 \%$ (30). According to Zheng et al. (25), who performed PK and DALK with APCS in different patients, the overall recurrence rate was $23 \%$ and inflammation occurred in $7.6 \%$ of the subjects. Wu et al. (24), who compared full-bed DLK with PK, noted 
Tab. 2 DALK with corneal allograft.

\begin{tabular}{|c|c|c|c|c|}
\hline \multirow{2}{*}{$\begin{array}{l}\text { Procedure type } \\
\text { Author }\end{array}$} & \multicolumn{4}{|c|}{ DALK with corneal allograft (graft type not exactly defined) } \\
\hline & Lyall et al. (27) & Ren et al. (28) & Sarnicola et al. (21) & Wang et al. (29) \\
\hline Year of publication & 2012 & 2016 & 2010 & 2012 \\
\hline Study location & Glasgow, UK & Zhejiang, China & Grosseto, Italy & Wuhan, China \\
\hline Study design & $\begin{array}{l}\text { Retrospective, } \\
\text { descriptive, } \\
\text { Case series }\end{array}$ & $\begin{array}{l}\text { Retrospective, } \\
\text { Case series }\end{array}$ & Case series & $\begin{array}{l}\text { Retrospective, } \\
\text { Case series }\end{array}$ \\
\hline $\begin{array}{l}\text { Total patients } \\
\text { enrolled in the study }\end{array}$ & 18 & 89 & 52 & 42 pts (43 eyes) \\
\hline $\begin{array}{l}\text { Total patients who } \\
\text { completed the study }\end{array}$ & 18 & 89 & 52 & 42 pts (43 eyes) \\
\hline $\begin{array}{l}\text { Patient demographic } \\
\text { characteristics }\end{array}$ & $\begin{array}{l}\text { Mean age: } 57 \\
38.8 \% \text { male }\end{array}$ & $\begin{array}{l}\text { Mean age } 47.1 \\
60.7 \% \text { male }\end{array}$ & $\begin{array}{l}\text { Mean age } 46.5 \\
61.5 \% \text { male }\end{array}$ & NA \\
\hline $\begin{array}{l}\text { Treatment } \\
\text { groups }\end{array}$ & 1 group & $\begin{array}{l}3 \text { groups } \\
\text { Folds-off Group }(n=27) \\
\text { Folds-on Group }(n=14) \\
\text { No-folds Group }(n=48)\end{array}$ & 1 group & 1 group \\
\hline $\begin{array}{l}\text { Dose and schedule } \\
\text { of interventions }\end{array}$ & $\begin{array}{l}\text { oral ACV } 400 \mathrm{mg} \\
\times 2 / \mathrm{d} \text { for } 12 \mathrm{~m} \\
\text { topical chloram- } \\
\text { phenicol } 0.5 \% \\
\text { for } 1 \mathrm{~m} \\
\text { dexamethasone } \\
0.1 \% \text { eye drops } \\
\times 4 / \mathrm{d} \text { for } 1 \mathrm{~m} \text {, } \\
\text { tapering for } 6-9 \mathrm{~m}\end{array}$ & $\begin{array}{l}\text { oral ACV } 400 \mathrm{mg} \times 5 / \mathrm{d} \text { for } \\
1 \mathrm{~m} \text {, tapering to } \\
400 \mathrm{mg} \times 2 / \mathrm{d} \text { for } 12 \mathrm{~m} \\
\text { tobramycin } 0.3 \% / \\
\text { dexamethasone } 0.1 \% \\
\text { eye drops tapering } \\
\text { for } 3 \mathrm{~m}\end{array}$ & $\begin{array}{l}\text { oral ACV } 800 \mathrm{mg} \times 3 / \mathrm{d} \\
\text { for } 2 \mathrm{~m} \text {, tapering to } \\
800 \mathrm{mg} \times 1 / \mathrm{d} \text { for long } \\
\text { term } \\
\text { topical antibiotics and } \\
\text { corticosteroid } \times 4 / \mathrm{d} \\
\text { for } 1 \mathrm{~m} \\
\text { dexamethasone drops } \\
\times 3 / \mathrm{d} \text { for the next } 1 \mathrm{~m} \\
\text { tapering to drops } \\
\times 2 / \mathrm{d} \text { for long term }\end{array}$ & $\begin{array}{l}\text { Preop.: } \\
\text { i.v. ACV } 250 \mathrm{mg} \times 3 / \mathrm{d} \text { for } 3 \mathrm{~d} \\
0.15 \% \mathrm{GCV} \text { ointment } \times 1 / \mathrm{d} \text { for } 3 \mathrm{~d} \\
0.1 \% \text { ACV eye drops } \times 4 / \mathrm{d} \text { for } 3 \mathrm{~d} \\
\text { tobramycin sulfate eye drops } \\
\times 4 / \mathrm{d} \text { for } 3 \mathrm{~d} \\
\text { Postop.: } \\
0.1 \% \text { ACV eye drops } \times 4 / \mathrm{d} \text { for } 6 \mathrm{~m} \\
\text { oral ACV } 400 \mathrm{mg} \times 3 / \mathrm{d} \text { for } 3 \mathrm{~m} \\
\text { tobramycin } 0.3 \% / \text { dexamethasone } 0.1 \% \\
\text { eye drops } \times 4 / \mathrm{d} \text { for } 3 \mathrm{w} \text { and replaced } \\
\text { with } 0.02 \% \text { fluorometholone } \\
\text { eye drops } \times 3 / \mathrm{d} \text { daily for } 5 \mathrm{~m} \\
\text { then } 0.15 \% \mathrm{GCV} \text { and tobramycin eye } \\
\text { ointments } \times 1 / \mathrm{d}\end{array}$ \\
\hline $\begin{array}{l}\text { Duration } \\
\text { of follow-up }\end{array}$ & $56 \mathrm{~m}$ & $50.4 \mathrm{~m}$ & $31 \mathrm{~m}$ & $29.1 \mathrm{~m}$ \\
\hline $\begin{array}{l}\text { Primary } \\
\text { outcomes }\end{array}$ & $\begin{array}{l}\text { Preop. BCVA: } \\
\text { logMAR } 1.51 \\
\text { Postop. BCVA: } \\
\text { logMAR } 0.82\end{array}$ & $\begin{array}{l}\text { Mean preop. BCVA } \\
\text { logMAR } 1.63 \\
\text { Folds-off Group: } \\
\text { logMAR } 0.42 \\
\text { Folds-on Group: } \\
\text { logMAR } 0.48 \\
\text { No-folds Group: } \\
\text { logMAR } 0.44\end{array}$ & $\begin{array}{l}\text { Preop. UVA 20/70 } \\
\text { Postop. UVA 20/40 }\end{array}$ & $\begin{array}{l}\text { Postop. BSCVA } \\
-20 / 100 \text { to } 20 / 40: 86 \%\end{array}$ \\
\hline Complications & $\begin{array}{l}\text { Recurrence: } 33.3 \% \\
\text { Rejection: } 50 \% \\
\text { IOP: } 27.7 \% \\
\text { Bacterial keratitis: } \\
27.7 \% \\
\text { Graft failure: } 27.7 \%\end{array}$ & $\begin{array}{l}\text { Recurrence: } 9 \% \text { ( } 8 \text { pts) } \\
\text { Rejection: } 4.5 \% \text { ( } 4 \text { eyes) } \\
\text { Microperforation: } \\
\text { 16.9\% (15 eyes) } \\
\text { Double minor anterior } \\
\text { chamber: } 10.1 \% \text { ( } 9 \text { eyes) } \\
\text { Corneal endothelial de- } \\
\text { compensation: } \\
\text { 3.4\% ( } 3 \text { eyes) } \\
\text { Posterior stromal folds: } \\
\text { 46.1\% ( } 41 \text { eyes) }\end{array}$ & $\begin{array}{l}\text { Recurrence: } 0 \% \\
\text { Rejection: } 0 \% \\
\text { Microperforations } \\
\text { (ruptures of DM): } 3.8 \% \\
\text { Endothelial cell loss } \\
(6-12 \mathrm{~m}): 205.32 \\
\text { cells } / \mathrm{mm}^{2}\end{array}$ & $\begin{array}{l}\text { Recurrence: } 14 \% \text { ( } 7 \text { cases) } \\
\text { Recurrence: } 9.3 \% \text { first year } \\
\text { Recurrence: } 16.3 \% \text { first } 2 \text { years } \\
\text { Rejection: } 2.3 \% \\
\text { Non-physiologic corneal graft } \\
\text { endothelial cell loss or dysfunction } \\
\text { was not observed }\end{array}$ \\
\hline
\end{tabular}

ACV: acyclovir; BCVA: best corrected visual acuity; BSCVA: Best spectacle-corrected visual acuity; DALK: deep anterior lamellar keratoplasty; DM: descemet membrane; folds-off group: the central stromal folds were peeled off with resultant bare descemet membrane; folds-on group: the folds were not removed because of the occurrence or high risk of descemet membrane perforation; GCV: ganciclovir, IOP: intraocular pressure; m: months; NA: Not applicable; No-folds group: stromal folds were not observed intraoperatively; postop: postoperative; preop: preoperative; pts: patients; UVA: uncorrected visual acuity

different complications such as recurrence, graft failure, microperforation, and increased IOP. Specifically, recurrence was observed in $10.3 \%$ and $20.6 \%$ with full-bed DLK and $\mathrm{PK}$, respectively, graft failure in $1.7 \%$ and $22.22 \%$, microperforation in $13.8 \%$ and $0 \%$, and high IOP in $6.9 \%$ and
38.1\% in full-bed DLK and PK group, respectively. Moreover, secondary glaucoma, cataract and wound dehiscence was observed in $3.4 \%$ of the subjects in the full-bed DLK group, in contrast to $4.8 \%, 32.6 \%$ and $7.9 \%$ in the PK group. 
Tab. 3 DALK with different graft types.

\begin{tabular}{|c|c|c|c|c|c|c|}
\hline Procedure type & DALK using ACT & \multicolumn{3}{|c|}{ DALK using precut ALC } & DALK with APCS & DALK using GCCTs \\
\hline Author & Li J. et al. (32) & \multicolumn{3}{|l|}{ Li J. et al. (31) } & Li S. et al. (22) & Liu et al. (26) \\
\hline Year of publication & 2011 & \multicolumn{3}{|l|}{2014} & 2019 & 2016 \\
\hline Study location & Zhejiang, China & \multicolumn{3}{|l|}{ Zhejiang, China } & Guangzhou, China & Shanghai, China \\
\hline Study design & $\begin{array}{l}\text { Prospective, randomized, } \\
\text { comparative study }\end{array}$ & \multicolumn{3}{|l|}{$\begin{array}{l}\text { Retrospective, } \\
\text { comparative, cohort }\end{array}$} & $\begin{array}{l}\text { Prospective, } \\
\text { cohort }\end{array}$ & $\begin{array}{l}\text { Retrospective, } \\
\text { Case series }\end{array}$ \\
\hline $\begin{array}{l}\text { Total patients } \\
\text { enrolled in the study }\end{array}$ & 68 & \multicolumn{3}{|l|}{48} & 39 & 27 \\
\hline $\begin{array}{l}\text { Total patients who } \\
\text { completed the study }\end{array}$ & 68 & \multicolumn{3}{|l|}{48} & 39 & 27 \\
\hline $\begin{array}{l}\text { Patient demographic } \\
\text { characteristics }\end{array}$ & $\begin{array}{l}\text { Mean age } 48.2 \\
53 / 68 \text { male }\end{array}$ & \multicolumn{3}{|l|}{$\begin{array}{l}\text { Mean age: } 42.2 \\
\text { FTS: male: } 63 \% \\
\text { ALC: male: } 62 \%\end{array}$} & $\begin{array}{l}\text { Mean age } 45.5 \\
25 / 39 \text { male }\end{array}$ & $\begin{array}{l}\text { Mean age } 40.8 \\
66.67 \% \text { male }\end{array}$ \\
\hline $\begin{array}{l}\text { Treatment } \\
\text { groups }\end{array}$ & $\begin{array}{l}2 \text { groups } \\
\text { Group 1: GCCT } \\
\text { Group 2: FCT } \\
\text { HSK: } 30 \text { pts (GCCT: 15, } \\
\text { FCT: 15) } \\
\text { Bacterial keratitis: } 15 \text { pts } \\
\text { (GCCT: 8, FCT: 7) } \\
\text { Fungal keratitis: } 14 \text { pts } \\
\text { (GCCT: 7, FCT: 7) } \\
\text { Ocular burns: } 9 \text { pts } \\
\text { (GCCT: 4, FCT: } 5 \text { ) }\end{array}$ & \multicolumn{3}{|c|}{$\begin{array}{l}2 \text { groups } \\
\text { FTS group (DALK with FTS): } \\
27 \text { pts } \\
\text { ALC group (DALK with } \\
\text { precut ALC): } 21 \text { pts }\end{array}$} & $\begin{array}{l}\text { Fungal keratitis } \\
22(56.4 \%) \\
\text { HSK } 7(17.9 \%) \\
\text { Bacterial keratitis } \\
5(12.8 \%) \\
\text { Acanthamoeba } \\
\text { keratitis } 4(10.3 \%)\end{array}$ & one group (HSK) \\
\hline $\begin{array}{l}\text { Dose and schedule } \\
\text { of interventions }\end{array}$ & $\begin{array}{l}\text { Topical antibiotics } \\
\text { and steroids tapering } \\
\text { dose } \\
\text { oral ACV tapering dose }\end{array}$ & \multicolumn{3}{|c|}{$\begin{array}{l}\text { Tobramycin eye-drops } \\
\text { tapering for } 3 \mathrm{~m} \\
\text { topical steroids } \\
\text { (dexamethasone) } \\
\text { oral ACV } 200 \mathrm{mg} \times 5 / \mathrm{d} \text { for } 3 \mathrm{~m}, \\
\text { tapering to } 400 \mathrm{mg} \times 2 / \mathrm{d} \text { for } 12 \mathrm{~m}\end{array}$} & $\begin{array}{l}\text { Oral ACV } 400 \mathrm{mg} \\
\times 2 / \mathrm{d} \text { for } 12 \mathrm{~m} \\
\text { Topical antiviral } \\
\text { medications (GCV } \\
\text { and interferon) for } \\
\text { at least } 3 \mathrm{~m}\end{array}$ & $\begin{array}{l}\text { Preop.: } \\
\text { oral ACV } 400 \mathrm{mg} \times 5 / \mathrm{d} \\
0.15 \% \mathrm{GCV} \text { ophthalmic gel } \\
\times 4 / \mathrm{d} \text { for } 3 \mathrm{w} \\
\text { tobramycin sulfate eye } \\
\text { drops } \times 4 / \mathrm{d} \text { for } 3 \mathrm{w} 0.02 \% \\
\text { fluorometholone eye drops } \\
\times 2 \text { for } 3 \mathrm{w} \\
\text { Postop.: } \\
\text { oral ACV } 400 \mathrm{mg} \times 5 / \mathrm{d} \text { in the } \\
\text { first } \mathrm{months} \text {, tapering to } \\
400 \mathrm{mg} \times 2 / \mathrm{d} \text { for } 12-18 \mathrm{~m} \\
0.15 \% \mathrm{GCV} \text { ophthalmic gel } \\
\times 4 / \mathrm{d} \text { for } 6 \text { - } 12 \mathrm{~m} \\
\text { tobramycin dexamethasone eye } \\
\text { drops } \times 4 / \mathrm{d} \text { for } 1 \mathrm{~m} \text {, substituted } \\
\text { for } 0.02 \% \text { fluorometholone eye } \\
\text { drops } \times 3 / \mathrm{d} \text { from then on }\end{array}$ \\
\hline $\begin{array}{l}\text { Duration } \\
\text { of follow-up }\end{array}$ & $24 \mathrm{~m}$ & \multicolumn{3}{|l|}{$36 \mathrm{~m}$} & $12 \mathrm{~m}$ & $24.4 \mathrm{~m}$ \\
\hline $\begin{array}{l}\text { Primary } \\
\text { outcomes }\end{array}$ & $\begin{array}{l}\text { (Mixed results for } \\
\text { all corneal diseases) } \\
\text { Preop. BCVA < 20/200: } \\
\text { - GCCT: } 78.8 \%(26 / 33) \\
\text { - FCT: } 74.2 \%(23 / 31) \\
\text { Postop. BCVA }(24 \mathrm{~m}) \text { - } \\
\text { improved in all cases } \\
\geq 20 / 40: \\
\text { - GCCT: } 57.6 \%(19 / 33) \\
\text { - FCT: } 54.8 \%(17 / 31)\end{array}$ & \multicolumn{3}{|c|}{$\begin{array}{l}\text { Preop. BSCVA: logMAR } 1.21 \\
\text { Postop. BSCVA: } \\
\text { - FTS: logMAR } 0.26 \\
\text { - ALC: logMAR } 0.28\end{array}$} & $\begin{array}{l}\text { (Mixed results for } \\
\text { all corneal diseases) } \\
\text { Preop. BCVA: } \\
\geq 20 / 40: 10.3 \% \\
\text { Postop. BCVA: } \\
\geq 20 / 40: 51.2 \% \\
\text { at } 12 \mathrm{~m}\end{array}$ & $\begin{array}{l}\text { Preop.: BSCVA HM / } 10 \mathrm{~cm} \text { to } \\
0.15 \text { decimals } \\
\text { Postop.: BSCVA } 0.41\end{array}$ \\
\hline Complications & $\begin{array}{l}\text { Recurrence: } 0 \% \\
\text { Stromal rejections: } \\
\text { - FCT group: } 3 \text { pts } \\
\text { - GCCT group: } 0 \text { pts }\end{array}$ & $\begin{array}{l}\text { Recurrence: } \\
\text { Rejection: } \\
\text { Microperforations: } \\
\text { Double anterior } \\
\text { chamber: } \\
\text { DM folds: }\end{array}$ & $\begin{array}{r}\text { FTS } \\
11.1 \% \\
0.0 \% \\
7.4 \% \\
14.8 \% \\
7.4 \%\end{array}$ & \begin{tabular}{|r|} 
ALC \\
$14.3 \%$ \\
$0.0 \%$ \\
$4.7 \%$ \\
$4.7 \%$ \\
$14.3 \%$
\end{tabular} & $\begin{array}{l}\text { Recurrence: } 14.2 \% \\
\text { Rejection: } 0 \% \\
\text { Graft failure: } 57.1 \% \\
\text { Graft melting: } \\
42.6 \%\end{array}$ & $\begin{array}{l}\text { Recurrence: } 7.4 \% \\
\text { Rejection: } 11.1 \% \\
\text { Microperforation: } 14.8 \% \\
\text { Double anterior chamber: } 7.4 \%\end{array}$ \\
\hline
\end{tabular}

ACV: acyclovir; ACT: Acellular Corneal Tissue; ALC: anterior lamellar cap; APCS: acellular porcine corneal stroma; BCVA: best corrected visual acuity; BSCVA: Best spectacle-corrected visual acuity; DALK: deep anterior lamellar keratoplasty; DM: descemet membrane FCT: fresh corneal tissue; FTS: fullthickness stroma; GCCT: glycerol-cryopreserved corneal tissue; GCV: ganciclovir; HM: hand movement; HSK: herpes simplex keratits; m: months; postop: postoperative; preop: preoperative; pts: patients; w: weeks 
Tab. 4 PK, PK vs DALK or full-bed DLK.

\begin{tabular}{|c|c|c|c|c|c|c|}
\hline Procedure type & PK & PK and DALK & \multicolumn{3}{|l|}{ Full-bed DLK and PK } & PK and DALK with APCS \\
\hline Author & Altay et al. (30) & Shimizu et al. (23) & \multicolumn{3}{|l|}{ Wu et al. (24) } & Zheng et al. (25) \\
\hline Year of publication & 2017 & 2017 & \multicolumn{3}{|l|}{2012} & 2019 \\
\hline Study location & Ankara, Turkey & Chiba, Japan & \multirow{2}{*}{\multicolumn{3}{|c|}{$\begin{array}{l}\text { Retrospective, comparative, } \\
\text { interventional case series }\end{array}$}} & Hangzhou, China \\
\hline Study design & $\begin{array}{l}\text { Retrospective, } \\
\text { Cohort }\end{array}$ & $\begin{array}{l}\text { Retrospective, com- } \\
\text { parative, Case series }\end{array}$ & & & & $\begin{array}{l}\text { Retrospective, } \\
\text { Case series }\end{array}$ \\
\hline $\begin{array}{l}\text { Total patients } \\
\text { enrolled in the study }\end{array}$ & 55 & 52 & \multicolumn{3}{|l|}{121} & 13 \\
\hline $\begin{array}{l}\text { Total patients who } \\
\text { completed the study }\end{array}$ & 55 & 52 & \multicolumn{3}{|l|}{121} & 13 \\
\hline $\begin{array}{l}\text { Patient demographic } \\
\text { characteristics }\end{array}$ & $\begin{array}{l}\text { Group 1: } \\
\text { mean age } 44.51 \\
78.6 \% \text { male } \\
\text { Group 2: } \\
\text { mean age } 41.76 \\
84.6 \% \text { male }\end{array}$ & $\begin{array}{l}\text { Mean age } 63.3 \\
35.3 \% \text { male }\end{array}$ & \multicolumn{3}{|c|}{$\begin{array}{l}\text { Full-bed DLK: mean age } 42.4 \text {, male } 37 / 58 \\
\text { PK mean age } 48.8 \text {, male } 44 / 63\end{array}$} & $\begin{array}{l}\text { Mean age } 61.9 \\
69.2 \% \text { male }\end{array}$ \\
\hline $\begin{array}{l}\text { Treatment } \\
\text { groups }\end{array}$ & $\begin{array}{l}\text { Group 1: } \\
(42 \text { pts) quiescent } \\
\text { herpetic corneal scar } \\
\text { Group 2: } \\
(13 \text { pts) corneal } \\
\text { descemetocele } \\
\text { or perforation }\end{array}$ & $\begin{array}{l}\text { Control group: } \\
18 \mathrm{pts} \\
\text { PK: } 17 \mathrm{pts} \\
\text { DALK: } 17 \mathrm{pts}\end{array}$ & \multicolumn{3}{|l|}{$\begin{array}{l}\text { Full-bed DLK: } 58 \text { eyes } \\
\text { PK: } 63 \text { eyes }\end{array}$} & $\begin{array}{l}\text { one group (PK only in } \\
5 \text { pts with perforation, } \\
\text { DALK in } 8 \text { pts with } \\
\text { corneal scar) }\end{array}$ \\
\hline $\begin{array}{l}\text { Dose and schedule } \\
\text { of interventions }\end{array}$ & $\begin{array}{l}\text { Topical } 0.3 \% \text { ofloxacin } \\
0.1 \% \text { dexamethasone } \\
\text { sodium phosphate eye } \\
\text { drops } \times 6 / \mathrm{d} \\
\text { Topical steroids for } \\
12 \mathrm{~m} \text {, tapering doses } \\
\text { Oral ACV } 400 \mathrm{mg} \\
\times 5 / \mathrm{d} \text { for } 3 \mathrm{~m} \text {, tapering } \\
\text { to } 400 \mathrm{mg} \times 2 / \mathrm{d} \\
\text { for } 12 \mathrm{~m}\end{array}$ & NA & \multicolumn{3}{|c|}{$\begin{array}{l}\text { Full-bed DLK: } \\
0.3 \% \text { ofloxacin or } 0.5 \% \text { levofloxacin } \\
\text { and } 0.1 \% \text { fluorometholone eyedrops } \\
\times 4 / \mathrm{d} \\
\text { topical steroids for } 12 \mathrm{~m} \text {, tapering dose } \\
200 \mathrm{mg} \text { topical } \mathrm{ACV} \times 5 / \mathrm{d} \text { for } 3 \mathrm{~m} \text {, } \\
\text { then } 400 \mathrm{mg} \times 2 / \mathrm{d} \text { for } 12-18 \mathrm{~m} \\
\mathrm{PK} \text { : } \\
0.1 \% \text { dexamethasone sodium phosphate } \\
\text { combined with } 0.3 \% \text { tobramycin } \\
\text { eyedrops } \times 4 / \mathrm{d} \\
\text { topical steroids for } 12 \mathrm{~m} \text {, tapering dose } \\
200 \mathrm{mg} \text { topical ACV } \times 5 \mathrm{~d} \text { for } 3 \mathrm{~m} \text {, } \\
\text { then } 400 \mathrm{mg} \times 2 / \mathrm{d} \text { for } 12-18 \mathrm{~m}\end{array}$} & $\begin{array}{l}\text { oral ACV } 0.4 \mathrm{~g} \times 5 / \mathrm{d} \\
\text { for } 1 \mathrm{~m} \text {, tapering to } \\
\times 2 / \mathrm{d} \text { for } 12 \mathrm{~m} \\
\text { antiviral eye ointment } \\
\times 4 / \mathrm{d} \text { for } 1 \mathrm{~m} \text {, tapering } \\
\text { to } \times 2 / \mathrm{d} \text { for } 3 \mathrm{~m} \\
\text { Corticosteroid eye drops } \\
\times 4 / \mathrm{d} \text { for } 3 \mathrm{~m} \text {, tapering } \\
\text { dose for long term } \\
\text { Artificial eye drops } \\
\times 4 / \mathrm{d} \text { for } 12 \mathrm{~m}\end{array}$ \\
\hline $\begin{array}{l}\text { Duration } \\
\text { of follow-up }\end{array}$ & $\begin{array}{l}\text { Group 1: } 19.8 \mathrm{~m} \\
\text { Group 2: } 26.15 \mathrm{~m}\end{array}$ & $12 \mathrm{~m}$ & \multicolumn{3}{|l|}{$46 \mathrm{~m}$} & $15.1 \mathrm{~m}$ \\
\hline $\begin{array}{l}\text { Primary } \\
\text { outcomes }\end{array}$ & $\begin{array}{l}\text { Preop. BCVA: } \\
\text { HM to logMAR } 0.7 \\
\text { Postop. BCVA: } \\
\text { - Group 1: 93\% } \\
\text { BCVA } \geq \log M A R 1.2 \\
\text { - Group 2: } 100 \% \\
\text { BCVA } \geq \log M A R 1.2\end{array}$ & $\begin{array}{l}\text { Control: } \\
\text { logMAR -0.03 } \\
\text { Preop.: } \\
\text { - DALK: logMAR } 1.16 \\
\text { - PK: logMAR } 1.65 \\
\text { Postop.: } \\
\text { - PK: logMAR } 0.48 \\
\text { - DALK: logMAR } 0.44\end{array}$ & \multicolumn{3}{|c|}{$\begin{array}{l}\text { Preop. BCVA: } \\
\text {-Full bed DLK: } 0.05 \text { decimals } \\
\text {-PK: CF } \\
\text { Postop. BCVA: } \\
\text { - Full-bed DLK: improvement in } 66.1 \% \\
\text { eyes } \\
\text { - PK: improvement in } 50.9 \% \text { eyes }\end{array}$} & $\begin{array}{l}\text { Prep. VA: } \\
\text { LP to } 0.02 \text { decimals } \\
\text { Postop.: } \\
\text { - improvement : } 69.2 \% \\
\text { - no improvement: } \\
\quad 30.8 \%\end{array}$ \\
\hline Complications & $\begin{array}{l}\text { Recurrence of HSK: } \\
28.57 \% \\
\text { Group 1: } \\
\text { - Graft rejection: } \\
\text { 9.52\% } \\
\text { - Graft failure: 19\% } \\
\text { Group 2: } \\
\text { - Graft rejection: } \\
\text { 23.07\% } \\
\text { - Graft failure: } 30.8 \%\end{array}$ & NA & $\begin{array}{l}\text { Recurrence: } \\
\text { Graft rejection: } \\
\text { Graft failure: } \\
\text { Microperforation: } \\
\text { High IOP: } \\
\text { Secondary glaucoma: } \\
\text { Cataract: } \\
\text { Wound dehiscence: }\end{array}$ & $\begin{array}{l}\text { Full-bed } \\
\text { DLK } \\
10.3 \% \\
0.0 \% \\
1.7 \% \\
13.8 \% \\
6.9 \% \\
3.4 \% \\
3.4 \% \\
3.4 \%\end{array}$ & \begin{tabular}{|l|} 
PK \\
\\
$20.6 \%$ \\
$41.3 \%$ \\
$22.22 \%$ \\
$0.0 \%$ \\
$38.1 \%$ \\
$4.8 \%$ \\
$32.6 \%$ \\
$7.9 \%$
\end{tabular} & $\begin{array}{l}\text { Recurrence: } 23 \% \\
\text { Rejection: } 0 \% \\
\text { Inflammation: } 7.6 \%\end{array}$ \\
\hline
\end{tabular}

ACV: acyclovir; BCVA: best corrected visual acuity; CF: counting fingers; DALK: deep anterior lamellar keratoplasty; Full-bed DLK: Full-bed deep lamellar keratoplasty; HM: hand movement; HSK: Herpes Simplex Keratitis; IOP: intraocular pressure; LP: light perception; m: months; m: months; NA: Not applicable; PK: penetrating keratoplasty; postop: postoperative; preop: preoperative; pts: patients; VA: visual acuity 


\section{QUALITY ASSESSMENT}

The assessment of study quality and the risk for bias is shown in the Table 1. Overall, 5 studies were classified as moderate $(22,24,30-32)$ in global rating, that means that the risk of bias is also moderate. On the other hand, 7 records had weak $(21,23,25-29)$ global rating and high risk of bias.

\section{DISCUSSION}

The present systematic review compared PK and DALK techniques in patients suffering from HSK-related corneal scarring. For the better understanding of our findings, the different available surgical procedures should be analyzed. PK is a full-thickness transplant procedure, in which a full-thickness resection of the patient's cornea is followed by transplantation of a full-thickness donor corneal graft. On the other hand, in DALK, host tissue is removed down to the DM and transplantation of a donor cornea is applied, following the removal of the donor endothelium (34). PK is indicated when all corneal layers (epithelium, stroma and endothelium) are affected. Thus, it seems that HSK cases which are involving the endothelium and are more severe would have more adverse outcomes than the less severe, not involving the endothelium HSK cases which are treated by DALK.

Our study outcomes indicate that both surgical approaches resulted in comparable improvement in VA. A direct comparison of the VA improvement between the two surgery groups was difficult to achieve because of the heterogeneity of the outcomes presentation. However, DALK demonstrated fewer complications in almost all reports except for one by Lyall et al. (27). A possible explanation of Lyall et al. for the increased rate of post-DALK complications was the fact that they used only $800 \mathrm{mg} /$ day of ACV. Graft failure or graft melting has also been associated with low dose of ACV, but also with the non-use of topical steroids and antibiotics, in the report of Li S. et al. (22). In fact, further to ACV, the increased rates of graft survival following DALK are attributed to the intact recipient's endothelium, which assumes function almost immediately following the surgical procedure. The recovery of the function of the endothelium is facilitated by local cortisone drops. In general, in 9 out of 10 studies examining DALK complications $(21-22,24-26,28-29,31-32)$, the graft rejection rate was between $0 \%$ and $23.07 \%$, while in one study (27), graft rejection occurred in $50 \%$ of DALK cases in a 56-month follow-up period. On the other hand, in the three studies examining PK complications $(24-25,30)$, the rate of graft rejection ranged between $0 \%$ and $41.3 \%$.

To the best of our knowledge, this is the first review to report on PK and DALK following HSK-related scarring. Our outcomes suggest that, despite the fact, that both surgical interventions result in comparable improvement outcomes in VA, DALK is associated with fewer complications. Higher graft survival rates are correlated with higher ACV doses (above $800 \mathrm{mg} /$ day), topical steroid and antibiotic drops.

Certain limitations of our study need to be noted. First, only few literature reports compared directly PK with DALK technique in HSK patients. As a consequence, many of our results were indirectly derived from descriptive studies or studies whose main object was the comparison of patient groups based on other criteria. In addition, the literature reports showed a great heterogeneity in the way the outcomes, especially the VA, were presented. Therefore, the direct comparison of the outcomes was challenging. Moreover, we only included studies with immunocompetent subjects, so eventually a significant number of immunodeficient cases was excluded. Finally, most of the articles received a moderate or weak global rating in the quality assessment control, due to the fact that they were non-randomized reports. There is no doubt that the inherent difference between PK and DALK could be clearly specified by randomized controlled trials (RCTs) that would compare sufficiently powered sample of patients with the same HSK severity who would be divided in PK- and DALK-groups. However, this kind of studies would arise ethical issues since patients with less severe HSK would receive a more invasive treatment like PK, and patients with more severe HSK would undergo a less invasive operation like DALK. Since PK is applied in more severe HSK cases than DALK, but also the visual outcomes of these surgical approaches are equally good, someone could suggest that PK is a better procedure compared to DALK. However, these surgical approaches were difficult to be practically compared as the final VA is not the only criterion for a successful operation. In fact, other criteria should be considered such as failure rate, peri- and postperative complications, and recurrence of herpetic keratitis in the graft. In addition to that, the two procedures have different indications as the DALK cannot be used when the $\mathrm{DM}$ and/or the endothelium have been compromised.

\section{CONCLUSIONS}

In terms of postoperative visual acuity, both PK and DALK demonstrate comparable efficacy. DALK, which is applied in less severe HSK cases, is associated with fewer complications and better graft survival rates. High dosages of ACV, topical steroids and antibiotics contribute significantly to improved postoperative outcomes.

\section{ACKNOWLEDGMENTS/DISCLOSURE}

No financial support was received for this study. None of the authors has any proprietary interests or conflicts of interest related to this submission. It is not simultaneously being considered for publication at any other journal.

\section{REFERENCES}

1. Gaynor BD, Margolis TP, Cunningham ET, Jr. Advances in diagnosis and management of herpetic uveitis. Int Ophthalmol Clin 2000; 40(2): 85-109.

2. Valerio GS, Lin CC. Ocular manifestations of herpes simplex virus. Curr Opin Ophthalmol 2019; 30(6): 525-31.

3. Weiner G. Demystifying the ocular herpes simplex virus. American Academy of Ophthalmology. (Accessed July 13 2020, at: https://www aao.org/eyenet/article/demystifying-ocular-herpes-simplex-virus.)

4. Azher TN, Yin XT, Tajfirouz D, Huang AJ, Stuart PM. Herpes simplex keratitis: challenges in diagnosis and clinical management. Clin Ophthalmol 2017; 11: 185-91. 
5. Group HEDS. Psychological stress and other potential triggers for recurrences of herpes simplex virus eye infections. Herpetic Eye Disease Study Group. Arch Ophthalmol 2000; 118(12): 1617-25.

6. Asbell PA. Valacyclovir for the prevention of recurrent herpes simplex virus eye disease after excimer laser photokeratectomy. Trans Am Ophthalmol Soc 2000; 98: 285-303.

7. Young RC, Hodge DO, Liesegang TJ, Baratz KH. Incidence, recurrence, and outcomes of herpes simplex virus eye disease in Olmsted County, Minnesota, 1976-2007: the effect of oral antiviral prophylaxis. Arch Ophthalmol 2010; 128(9): 1178-83.

8. Tsatsos M, MacGregor C, Athanasiadis I, Moschos MM, Hossain P, Anderson D. Herpes simplex virus keratitis: an update of the pathogenesis and current treatment with oral and topical antiviral agents. Clin Exp Ophthalmol 2016; 44(9): 824-37.

9. Liesegang TJ, Melton LJ, Daly PJ, Ilstrup DM. Epidemiology of ocular herpes simplex. Incidence in Rochester, Minn, 1950 through 1982. Arch Ophthalmol 1989; 107(8): 1155-9.

10. Shimazaki J, Shimmura S, Ishioka M, Tsubota K. Randomized clinical trial of deep lamellar keratoplasty vs penetrating keratoplasty. Am J Ophthalmol 2002; 134(2): 159-65.

11. Sarnicola V, Toro P, Sarnicola C, Sarnicola E, Ruggiero A. Long-term graft survival in deep anterior lamellar keratoplasty. Cornea 2012; 31(6): 621-6.

12. Sarnicola E, Sarnicola C, Sabatino F, Tosi GM, Perri P, Sarnicola V. Early Deep Anterior Lamellar Keratoplasty (DALK) for Acanthamoeba Keratitis Poorly Responsive to Medical Treatment. Cornea 2016; 35(1): 1-5.

13. Epstein RJ, Seedor JA, Dreizen NG et al. Penetrating keratoplasty for herpes simplex keratitis and keratoconus. Allograft rejection and survival. Ophthalmology 1987; 94(8): 935-44.

14. Ing JJ, Ing HH, Nelson LR, Hodge DO, Bourne WM. Ten-year postoperative results of penetrating keratoplasty. Ophthalmology 1998; 105(10): 1855-65.

15. Halberstadt M, Machens M, Gahlenbek KA, Bohnke M, Garweg JG. The outcome of corneal grafting in patients with stromal keratitis of herpetic and non-herpetic origin. Br J Ophthalmol 2002; 86(6): 646-52.

16. Reinhart WJ, Musch DC, Jacobs DS, Lee WB, Kaufman SC, Shtein RM. Deep anterior lamellar keratoplasty as an alternative to penetrating keratoplasty a report by the american academy of ophthalmology. Ophthalmology 2011; 118(1): 209-18.

17. Gundersen T. Conjunctival flaps in the treatment of corneal disease with reference to a new technique of application. AMA Arch Ophthalmol 1958; 60(5): 880-8.

18. Foster CS, Barney NP. Systemic acyclovir and penetrating keratoplasty for herpes simplex keratitis. Doc Ophthalmol 1992; 80(4): 363-9.

19. Moher D, Liberati A, Tetzlaff J, Altman DG, Group P. Preferred reporting items for systematic reviews and meta-analyses: the PRISMA Statement. Open Med 2009; 3(3): e123-30.

20. Effective Public Health Practice Project. Quality assessment tool for quantitative studies. (Accessed July 13 2020, at: https://www.nccmt. $\mathrm{ca} / \mathrm{knowledge-repositories/search/14.)}$

21. Sarnicola V, Toro P. Deep anterior lamellar keratoplasty in herpes simplex corneal opacities. Cornea 2010; 29(1): 60-4.

22. Li S, Li M, Gu L, et al. Risk factors influencing survival of acellular porcine corneal stroma in infectious keratitis: a prospective clinical study. J Transl Med 2019; 17(1): 434.

23. Shimizu E, Yamaguchi T, Tomida D, et al. Corneal Higher-order Aberrations and Visual Improvement Following Corneal Transplantation in Treating Herpes Simplex Keratitis. Am J Ophthalmol 2017; 184: $1-10$.

24. Wu SQ, Zhou P, Zhang B, Qiu WY, Yao YF. Long-term comparison of full-bed deep lamellar keratoplasty with penetrating keratoplasty in treating corneal leucoma caused by herpes simplex keratitis. Am J Ophthalmol 2012; 153(2): 291-9.e292.

25. Zheng J, Huang X, Zhang Y, et al. Short-term results of acellular porcine corneal stroma keratoplasty for herpes simplex keratitis. Xenotransplantation 2019; 26(4): e12509.

26. Liu X, Zhou Q, Huang X, Liu Z, Bi Y. Clinical evaluation of deep anterior lamellar keratoplasty using glycerol-cryopreserved corneal tissues for refractory herpetic stromal keratitis: An observational study. Medicine (Baltimore) 2016; 95(39): e4892.

27. Lyall DA, Tarafdar S, Gilhooly MJ, Roberts F, Ramaesh K. Long term visual outcomes, graft survival and complications of deep anterior lamellar keratoplasty in patients with herpes simplex related corneal scarring. Br J Ophthalmol 2012; 96(9): 1200-3.

28. Ren Y, Wang H, Zheng Q, et al. Long-Term Outcomes of Deep Anterior Lamellar Keratoplasty Treating Posterior Stroma-Implicated Herpetic Corneal Opacities. Cornea 2016; 35(3): 299-304.

29. Wang J, Zhao G, Xie L, Chen M, Zhao J. Therapeutic effect of deep anterior lamellar keratoplasty for active or quiescent herpetic stromal keratitis. Graefes Arch Clin Exp Ophthalmol 2012; 250(8): 1187-94.

30. Altay Y, Tamer S, Kaya AS, Balta O, Burcu A, Ornek F. The outcome of penetrating keratoplasty for corneal scarring due to herpes simplex keratitis. Arq Bras Oftalmol 2017; 80(1): 41-5.

31. Li J, Ma H, Zhao Z, et al. Deep anterior lamellar keratoplasty using precut anterior lamellar cap for herpes simplex keratitis: a long-term follow-up study. Br J Ophthalmol 2014; 98(4): 448-53.

32. Li J, Yu L, Deng Z, et al. Deep anterior lamellar keratoplasty using acellular corneal tissue for prevention of allograft rejection in highrisk corneas. Am J Ophthalmol 2011; 152(5): 762-70.e763.

33. Anwar M, Teichmann KD. Big-bubble technique to bare Descemet's membrane in anterior lamellar keratoplasty. J Cataract Refract Surg 2002; 28(3): 398-403.

34. Shimmura S, Shimazaki J, Tsubota K. Therapeutic deep lamellar keratoplasty for cornea perforation. Am J Ophthalmol 2003; 135(6): 896-7.

35. King JH, Jr., Mc TJ, Meryman HT. Preservation of corneas for lamellar keratoplasty: a simple method of chemical glycerine-dehydration. Trans Am Ophthalmol Soc 1961; 59: 194-201.

36. Heindl LM, Riss S, Bachmann BO, Laaser K, Kruse FE, Cursiefen C. Split cornea transplantation for 2 recipients: a new strategy to reduce corneal tissue cost and shortage. Ophthalmology 2011; 118(2): 294-301.

37. Heindl LM, Riss S, Laaser K, Bachmann BO, Kruse FE, Cursiefen C. Split cornea transplantation for 2 recipients - review of the first 100 consecutive patients. Am J Ophthalmol 2011; 152(4): 523-32. e522.

38. Shi WY, Xie LX. [Focus on the clinical application of the first artificial bioengineered cornea in China]. Zhonghua Yan Ke Za Zhi 2016; 52(3): 161-3.

39. Zhang MC, Liu X, Jin Y, Jiang DL, Wei XS, Xie HT. Lamellar keratoplasty treatment of fungal corneal ulcers with acellular porcine corneal stroma. Am J Transplant 2015; 15(4): 1068-75.

40. Rose ML. Role of endothelial cells in allograft rejection. Vasc Med 1997; 2 (2): 105-14.

41. Fan S, Stojanovic D, Malvankar-Mehta MS, Hutnik C. Treatment of herpes zoster ophthalmicus: a systematic review and Canadian cost-comparison. Can J Ophthalmol 2018; 53(2): 117-23. 